\title{
Researching the Complexities of the School Subject Swedish as a Second Language: A Linguistic Ethnographic Project in Four Schools
}

\author{
Christina Hedman *(D) and Ulrika Magnusson *(D) \\ Department of Teaching and Learning, Stockholm University, SE-106 91 Stockholm, Sweden \\ * Correspondence: christina.hedman@isd.su.se (C.H.); ulrika.magnusson@isd.su.se (U.M.)
}

check for

updates

Citation: Hedman, Christina, and Ulrika Magnusson. 2021. Researching the Complexities of the School Subject Swedish as a Second Language: A Linguistic Ethnographic Project in Four Schools. Languages 6: 205. https://doi.org/10.3390/

languages6040205

Academic Editors: Åsa Wedin and Boglárka Straszer

Received: 22 September 2021 Accepted: 30 November 2021 Published: 10 December 2021

Publisher's Note: MDPI stays neutral with regard to jurisdictional claims in published maps and institutional affiliations.

Copyright: (c) 2021 by the authors. Licensee MDPI, Basel, Switzerland. This article is an open access article distributed under the terms and conditions of the Creative Commons Attribution (CC BY) license (https:// creativecommons.org/licenses/by/ $4.0 /)$.

\begin{abstract}
This article focuses on language education policy for language learners in Sweden by building on a synthesis of findings from a research project on the school subject Swedish as a second language (SSL). The project was located in three upper secondary schools and one primary school with a large proportion of migrant students, of whom a majority studied SSL. We present previously published core findings, as well as revisit data for new analyses. The overarching aim is to contribute new knowledge on the complexities of arranging for sustainable, equitable and high-quality language educational provisions that include the teaching and learning of the language of schooling, through the lens of SSL. First, we outline and discuss the relatively unique design of SSL and discourses surrounding the subject, and also make some international comparisons with English as an Additional Language. Secondly, we discuss the role of pedagogical scaffolding of advanced literacy and literary content, and of multilingual aspects in SSL, as well as examine policy frictions in the data. We conclude by reflecting on the role of teacher competences and research methodology. Researching a second language subject is to stand in the crossroad of macro policy, the theory and practice of language education, and equity. All these aspects need to be considered to reach sustainable educational goals.
\end{abstract}

Keywords: language policy; second language teaching and learning; Swedish as a second language; multilingualism; policy friction

\section{Introduction}

\subsection{A Project on SSL in Upper Secondary School and Primary School}

The school subject Swedish as a second language (SSL), aimed at language learners of Swedish, the language of majoritized status in Sweden and its educational system, was enacted in the curriculum from primary school to upper secondary level in 1995 with a specific syllabus for each level. For students in SSL, the subject replaces the subject Swedish (cf. the notion of Swedish Language Arts, henceforth referred to as SWE) and gives the same qualifications to upper secondary and tertiary levels. This parallel design implies that the curricular goals of high academic content are largely similar, while the ways to reach these goals differ between the two subjects (the Swedish National Agency for Education 2017). SSL includes both the teaching of language and literature, although the history of language and literature and literary concepts are treated in less detail in SSL. The SSL syllabi also relate to the specifics of second language development, and, in upper secondary school, to multilingual development (see further below). In upper secondary school, students choose which one of the two subjects to study, whereas, for lower levels, this decision is made by the school principal, often based on an SSL teacher's recommendations. A specific type of teacher education is necessary to be qualified to teach SSL (with at least 90 ECTS credits at upper secondary level, and 30-45 ECTS credits at lower levels), whereas a different type is required to teach SWE. Importantly, students studying SSL are taught in mainstream classes in all other subjects; thus, SSL is not the 
equivalent of preparatory classes where students are separated from the school community for the entire school day. SSL and SWE are taught as different classes, but in schools with low numbers of students in SSL, the two subjects are sometimes taught in the same classroom. In fact, SSL differs from many second language practices from an international perspective, particularly with respect to specialized teacher training and a parallel design with inherent high academic content (see Hedman and Magnusson 2020a). In addition, the introduction of SSL was not based on an assimilationist policy. Instead, the intentions were to facilitate functional bilingualism among new country citizens through the study of SSL in conjunction with the so-called Mother Tongue subject encompassing the teaching of minoritized languages (Tingbjörn 2004; see Hedman and Magnusson 2020a). This implies a recognition of the language learners' multilingual repertoire.

Nevertheless, SSL represents an ideologically charged field, as evident in an array of publications from public authorities, public debate and the academic field, constituting competing discourses (Hedman and Magnusson 2018). There is, however, little empirical research on SSL, which was an important starting point for our project on practices and ideologies in SSL, in which we conducted classroom ethnography in four schools between 2016 and 2019 from the perspectives of students and teachers, as well as policy. ${ }^{1}$ The project comprises two main parts: In sub-study I, we conducted ethnographic fieldwork in the classrooms of three SSL teachers in three linguistically diverse schools, respectively, during the course of more than 1.5 years. The teachers were qualified to teach SSL, and they each had long-term experience teaching in linguistically diverse classrooms. In substudy II, we conducted fieldwork in an introductory group taught by two SSL teachers during the course of more than two years in a linguistically diverse primary school (ages 7-12). During this period, we also observed the teaching in one of the SSL classes. ${ }^{2}$ A majority of the students at all schools studied came from migrant-dense socioeconomically vulnerable areas.

Guiding questions of the project were what characterized the SSL teaching practices, from the viewpoint of teachers and students, and in relation to discourses surrounding the subject. We chose to include highly qualified and experienced teachers in linguistically heterogeneous schools, as we wished to study SSL where it could be assumed that the teaching was realized in accordance with original intentions. Project data consisted of audiorecordings of classroom observations and interviews with teachers, the school principal and students, teaching materials and observational fieldnotes. Theoretically, we were guided by an interest in second language teaching and learning, as well as sociolinguistics and educational policy. We approached the research settings as academics from within the field of Swedish as a second language and multilingualism, and as mother-tongue speakers of Swedish. Relying on a linguistic ethnographic lens (cf. Copland et al. 2015), we observed and analyzed the teaching of one SSL teacher at each of the three upper secondary schools and two SSL teachers in the primary school.

In this paper, the overarching goal is to contribute new knowledge on the complexities of arranging for sustainable, equitable and high-quality language educational provisions that include the teaching and learning of the language of schooling, through the lens of SSL. More specifically, the aim is to present, and critically discuss the complexities with this particular second language subject, both as a design and a practice, from the perspectives of the stakeholders. For this purpose, we structure our discussions around some core findings through revisiting partly new data, beginning with discourses on SSL in the academic field (Hedman and Magnusson 2018), which we relate to policy research on English as an Additional Language. Thereafter we discuss two core findings from the three upper secondary schools (sub-study I): (1) the role of teacher expertise in pedagogical scaffolding of advanced content, and (2) the role of multilingualism in the curriculum. We also discuss instances of policy friction (Jaspers 2015) identified at the local school level. As discussed by Jaspers, a school may host different and even contradictory beliefs on language use, which was evident in our data. We discuss how such policy friction in students' and teachers' local discourses reproduce or challenge overall discourses on SSL. Chosen data 
illustrate these core findings, which also include new examples and analyses that reinforce our points and the aims of this paper.

Regarding sub-study II, we further highlight and discuss the SSL teachers' pedagogical scaffolding of literacy and literature and the role of multilingualism, as manifested via a collaborative practice. The data from sub-study II are not previously published. Also, sub-study I includes some new analyses that have not been published previously. The paper closes with a concluding discussion, including the role of teacher competences and research methodology as evident from our re-analysis of the project findings.

\subsection{Colliding and Crossing Discourses on SSL}

On the basis of publications addressing SSL within the academic field in Sweden 1995-2018, we analyzed discourses on SSL in relation to equality (Hedman and Magnusson 2018). Our analyses pointed to a tension between language educational aspects (equalityas-equal-opportunities, Westling Allodi 2007) versus social aspects with an emphasis on social inclusion in schools (equality-as-same-for-all, Westling Allodi 2007). Advocates for the introduction of SSL, on the one hand, argued for a need to acknowledge diversity and different language educational needs. A rationale was the prevailing monolingual norm in the Swedish school, identified as a main problem, implying a difference blindness (see Lindberg 2008). On the other hand, those in favor of mainstreaming, or inclusion, did not emphasize aspects of language and language learning but instead argued that SSL could be both a stigmatizing and discriminatory practice (see Hedman and Magnusson 2018).

As a point of comparison, concerns that were raised about separating second language students were also a reason why English as a Second Language (ESL)/English as an Additional Language (EAL) was abolished as a separate teaching practice in England, for the sake of "mainstreaming" (e.g., Leung 2016, 2019; see also a similar process in Norway, regarding Norwegian as a second language, Kulbrandstad and Kulbrandstad 2008). In a recent re-analysis of this process in England, Leung (2019) points out drawbacks of mainstreaming, reminiscent of the aforementioned reference to "difference blindness" in the Swedish debate.

According to Leung (2019), "a redefined vision of a pluralist society in a multiethnic and multilingual context has led to a view which favors social integration through common and undifferentiated membership in mainstream processes" (p. 310). By downplaying differences, Leung (2019) argues, mainstreaming "takes priority over English Language teaching and learning" (p. 310), based on an equation of first and second/additional language development, which "made it possible to move away from the need for differentiated pedagogy and curriculum" (Leung 2016, p. 164). As a consequence, the idea that second language learning will happen through mere immersion in the English language was also justified (cf. Conteh 2018). This is in line with discourses in the Swedish context, which prioritize physical inclusion in an education providing "same for all" without considering language learning issues (see Hedman and Magnusson 2018).

Key tenets in the Swedish debate have been, on the one hand, the suggestion to "widen" the SWE subject to include all students, except beginner learners of Swedish. On the other hand, the "responsibility of all teachers" is stated, implying that language dimensions should be included in the work of teachers in general. Notwithstanding the value of educating all teachers on the role of language in education (cf. Kulbrandstad and Kulbrandstad 2008), these aforementioned suggestions-and their deontic stance-are generally not evaluated in relation to empirical studies, or in relation to the potential absence of SSL teachers. Nor are the SSL teachers' expertise vis-à-vis the expertise of other subject teachers, and their implications for classroom practices, assessed (see Creese 2010, with respect to the status of ESL vs. science; also Leung 2016, 2019). Leung (2016) finds that mainstreaming of EAL in England has affected available resources, as there is no EAL curriculum, no EAL teacher education and no specific assessment for EAL students (Leung 2016, p. 169). One of Leung's main points is that it is unfortunate that "alternative 
curricular models and provisions" — apart from mainstreaming-tend to not be considered (Leung 2016, p. 198). The Swedish example thus provides a different educational choice.

In light of such discussions on language educational provisions for second/additional ${ }^{3}$ language students, and their attested complexities, we discuss SSL as an example of a curricular model for second language education (see above) on the basis of the two aforementioned sub-studies.

\section{Sub-Study I: The Three Upper Secondary Schools}

\subsection{The SSL Teachers' Scaffolding of Advanced Content}

In our fieldwork, we collected fieldnotes from the SSL classes of three teachers (Sandra at Pine, Stephen at Rowan, and Wera at Birch) and audio-recordings of interviews during the course of more than 1.5 years (in total, 58 lessons, with 20-25 students for each lesson). In these three schools, a majority of the students studied SSL; thus, SSL was not an exception. Of the 15 students who were interviewed, several chose to do so in pairs or triads; each interview lasted approximately one hour. A majority of the students (10) had arrived in Sweden during middle or secondary school, and five were born in Sweden. Both researchers conducted the interviews in a separate room at the schools. The teachers were interviewed individually by both researchers.

In one paper, we focused specifically on the students (Hedman and Magnusson 2020a), as learner perspectives in SSL are largely lacking (see, however, Bjuhr 2019; Siekkinen 2021). We conducted the student interviews with individuals or as pairs or groups with 15 students in SSL in their final or penultimate year of upper secondary school. Our main inquiry was both why the students had chosen SSL, as opposed to the more prestigious subject Swedish, and why they had continued to study SSL throughout upper secondary. We found this to be of interest since (1) the students are entitled to make these choices themselves at the upper secondary school level, as opposed to the compulsory school where the school decides on this matter, and (2) there are reasons to gain insight into why students choose SSL over SWE, considering the possible stigmatization of studying SSL, a subject of lower prestige (Fridlund 2011; Torpsten 2008).

A prominent reason for choosing SSL was the opportunities afforded for extensive pedagogical scaffolding of advanced academic content (Hedman and Magnusson 2020a). To situate SSL in an international context, we believe it to be important to point out that the teaching was directed toward meaningful language use in writing, classroom interaction and the reading of fiction and factual texts, as opposed to decontextualized basic reading and writing. In Sandra's SSL course, in the final year of upper secondary school, we followed a theme on social class. A focus was on the teaching of the expository genre, one of the genres addressed in the SWE and SSL syllabi. For this theme, a short text on Pierre Bourdieu's concept of capital was central, exploring the idea of cultural rather than economic capital. They also read two articles illustrating the theoretical concepts: the first by a journalist describing her experiences as a working-class child entering a new world as an art student, and the second by the football player Zlatan Ibrahimović, rendering his experiences of growing up in a low-status neighborhood in Malmö.

Excerpt 1 exemplifies how Sandra strived to scaffold a girl in the final year of upper secondary school to make a stronger case through coherent argumentation (see Appendix A for original transcripts in Swedish). The excerpt also illustrates how Sandra's feedback moved between the academic content, the textual level and individual wordings, including grammar. The excerpt begins in the midst of a discussion on the economic and cultural side to the notion of capital.

In their explorations of capital and social class, Sandra and the student acknowledge that what is considered valuable knowledge differs between contexts. This is exemplified both in one of the articles and the student's own experiences (such as the value of being good at body building). The excerpt illustrates Sandra's recurring efforts to anchor the idea of social class and cultural capital in the students' realities. The excerpt also includes a correction of grammar and expansion of lexical knowledge, when Sandra asks for the 
idiomatic morphology of köpa ('buy') in the past tense, as well as remarks on the choice of verb for "spending time" in Swedish, suggesting tillbringa instead of spendera. Sandra's scaffolding was built on her knowledge of the needs of each student, and the level of handover of responsibility to the students thus varied. In the case illustrated in excerpt 1 , the handover is not very prominent.

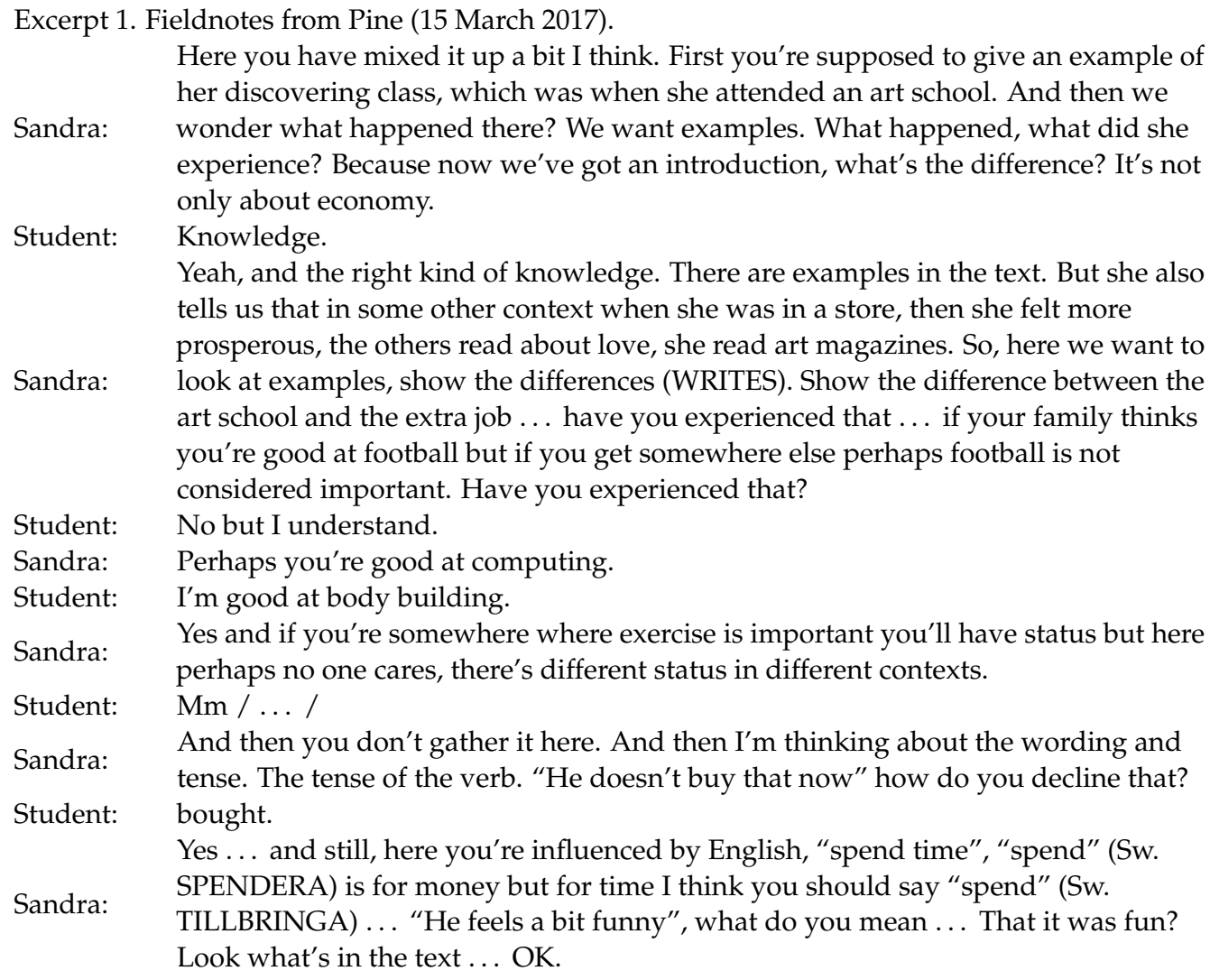

The students participating in the interviews expressed, in particular, an appreciation of their teachers' interactive scaffolding, and they explained in various ways what constituted this support. For example, the SSL teacher was found to be more student oriented and tended not to leave the students until it was clear that they understood the task: "so everybody understands, that's guaranteed", as expressed by one student in Sandra's class (Hedman and Magnusson 2020a, p. 9). The SSL teacher's meaning-making is further illustrated in an incidence at Rowan (building on an extended memo from fieldnotes, 12 December 2016, cf. Emerson 2004), where all final year students were summoned by the "first teacher" in Swedish for a lecture on how the upcoming National Tests in Swedish should be assessed by the teachers. We noted how the SSL teacher Stephen, who was also present, was called upon by the students to clarify details. From the reactions of the students, he seemed to convey and elaborate on this information in comprehensible ways. We find this to be indicative of a broader pattern in our data, regarding the SSL teachers' "explanatory force".

Stephen's pedagogical scaffolding was further evident in analyses of audio-recorded examining literary talks on the ancient novel The tale of a manor by Selma Lagerlöf (1899), through the use of a graphic novel (Ivarsson 2013). These dialogues were characterized by verbal elaborations instigated by Stephen and reflected the significance of using multimodal resources as a means for making meaning of advanced texts. A focus on meaningful language use, in tandem with advanced content, was thus evident also in the reading of literary texts. In excerpt 2, Zara, from Birch, describes how interaction with her teacher Wera resulted in an understanding of the novel One Eye Red by Jonas Hassen Khemiri (Khemiri 2003; see Hedman and Magnusson 2020a, p. 8). 
Excerpt 2. Interview with student Zara at Pine.

Um in Swedish, don't know, well the teachers expected us to know what is written, and I had difficulties with reading comprehension and still it like didn't help, we were expected to know it all but, now since I came to Wera [the SSL teacher], she said, then she went through like even more in detail and it got much clearer so now I

Zara: understand things better. For example, we read this "An Eye Red" and um we read the book, Wera had already read it before I think. So when we didn't understand things we went to her, so she said "well yes he says this and that, what do you think he says, he said this before", um tried to connect them like that and so, she used to give us clues, how clues, how we can understand the text.

Researcher:Does it work?

Yes it worked very well, I understood, it was the first book that I understood fully

Zara: [laughter] yes well I usually understand when I read books too. (Hedman and Magnusson 2020a, p. 8)

Excerpt 2 reflects the fact that students do not get enough support in the classroom to negotiate and understand literary texts. To Zara, this was a new experience in Wera's SSL classroom.

In sum, the insights outlined so far highlight the teaching of both language and literature, and also show that extensive pedagogical scaffolding can make literature accessible without using simple texts. This pedagogical scaffolding was also reflected in the students' portrayals of SSL as a space that afforded them opportunities to understand advanced literacy and academic content, as well as literature (Hedman and Magnusson 2020a). These positive evaluations could further be understood in relation to the local status of the SSL teachers at the schools. Both Sandra and Stephen were also teachers of SWE, and förstelärare (first teacher, see above) of SSL. Their expertise on teaching and assessing second language development was thus formally recognized among colleagues, and they both found SSL to have a high prestige locally. We found the teachers' expertise to be frequently called for by teachers of other subjects (Hedman and Magnusson 2020b). These findings differ from those realized in other second language learning contexts, such as Steven Talmy's fieldwork on ESL for recently arrived students in Hawaii (e.g., Talmy 2015). They were subjected to undemanding and age-inappropriate content outside of the curriculum taught by unqualified teachers and were, in addition, addressed in pejorative terms (see also Hedman and Magnusson 2020a, p. 3).

\subsection{The Role of Curricular Multilingual Aspects in SSL}

Another key finding was the role some students assigned to SSL in terms of multilingualism, as reported in Hedman and Magnusson (2019). Here, we focus on the overarching curricular goal to "strengthen the students' multilingualism" (Swedish National Agency for Education 2013, in Hedman and Magnusson 2019, p. 2), which was brought to our attention by some students. The following passage in the syllabus for upper secondary school is illustrative of this goal:

The subject contributes to strengthening students' multilingualism and confidence in their own language ability [ ... ] The students shall also be given the opportunity to reflect on their multilingualism and their prerequisites to conquer and develop a functional and rich second language in Swedish society. [ ... ] Multilingualism is an asset for the individual as well as for society, and by comparing language knowledge and language experiences with others the students shall be given the opportunity to develop a better understanding of what function language has for communication, thinking and learning.

(Swedish National Agency for Education 2013, our transl., also quoted in Hedman and Magnusson 2019, p. 2)

Some students referred to these goals as a primary reason for studying SSL, as evident in excerpt 3 (see Hedman and Magnusson 2019, pp. 10-11). 
Excerpt 3. Interview with student Fjodar at Birch.

Researcher: And then we wonder why you chose Swedish as a second language? Ehm, well, Swedish as a second language and Swedish as a first language do differ

Fjodar: to large extents, and in SSL it is part of the course to sort of connect with your mother tongue.

Researcher: Yes, okay.

Fjodar: Well, to be able to connect to that somehow, it is after all part of one's identity to

Researcher: Yes.

Fjodar: $\quad$ That's why I chose SSL. (Hedman and Magnusson 2019, pp. 10-11).

Fjodar's statement expresses how he relates the multilingual aspects of the SSL syllabus to "one's identity" and sense of belonging. Other students also related to experiences working with language comparison tasks, as part of the SSL syllabus, as an important learning task (Hedman and Magnusson 2019, p. 8). For example, Dana, a student at Rowan, emphasized how the language comparison tasks had made her more "aware" of her own language learning process. She also pointed out that this type of metalinguistic awareness was not taught in SWE, as it is not part of the SWE syllabus (interview, see Hedman and Magnusson 2019, p. 8).

During the course of our visits, multilingual aspects emerged in the classrooms with different emphasis and orientation. As is the case with the Swedish curriculum in general, the overarching goals on multilingual development are loosely formulated, and may thus be applied by the teachers to various degrees and in different ways. However, work on contrastive linguistic tasks occurred in all three schools, as knowledge derived from such tasks forms part of the SSL course requirements, which are graded. Nevertheless, two of the teachers, Wera and Stephen, extended their focus on multilingualism beyond this specific curricular requirement. At Birch in particular, Wera was found to engage extensively in her students' multilingual repertoire as an asset, through a teacher discourse that oriented towards empowerment of the students (Hedman and Magnusson 2019). Wera used, for example, her own multilingualism and that of her students to illustrate different aspects of the curricular content in a theme on sociolinguistics. In this theme, she emphasized her and the students' shared experiences of immigration and Swedish language learning in classroom interaction. She also applied an inclusive we/us with the students by which being multilingual was targeted as something desirable and enviable (Hedman and Magnusson 2019, p. 10). Although Swedish was never contested as the language of instruction, the multilingual repertoires became most salient in her classes (Hedman and Magnusson 2019).

At Rowan, Stephen explicitly acknowledged the importance of the students' languages other than Swedish, as a means for learning subject content in Swedish. Wera, however, also stressed that the students' multilingual competencies were a resource and an asset per se. As a corollary, students in Wera's and Stephen's classes expressed the value of their multilingualism and saw SSL as a place for recognition of and connection with their "mother tongues" (excerpt 3 ). Figure 1 depicts how these curricular goals on multilingualism were interpreted and implemented to various degrees, and in different ways, in the three schools.

Less

Pine

course requirements

\section{Rowan}

+acknowledgment
More

Birch

+empowering, + asset

Figure 1. Degrees of focus on students' multilingual repertoires.

In sum, the curricular multilingual goals explored in Hedman and Magnusson (2019) were found to be enacted through empowering discourses in Wera's classrooms-seemingly of importance for the students-and in opportunities of learning about language, and, thus, to some extent also of learning language (Halliday 1993). Learning through language (Halliday 
1993) by contrast, occurred through Swedish in all three schools (Hedman and Magnusson 2019). When relating to the performative functions of these curricular goals, as in Hedman and Magnusson (2019), we also foreground the potentials of a widened curricular space for multilingualism (cf. Hornberger 2005) to be better able to include the students' multilingual repertoire in SSL as well as in other subjects.

\subsection{Policy Friction and Ideologies on "Swedishness" and First and Second Languages}

SSL as an ideologically charged educational practice also came to the fore when discussing the initial choice of opting for SSL or SWE (cf. Leung 2019). Some of the students in our project expressed previous initial concerns regarding this choice, for example, regarding possible stigmatization of being an SSL student in terms of a hindrance for future prospects, such as future employment (cf. Siekkinen 2021). In the three schools, there were, however, opportunities to discuss this initial choice with SSL and SWE teachers as well as study guides, on the basis of initial Swedish proficiency assessments (Hedman and Magnusson 2020a). This initial procedure seemed to have been important for the students' choices, along with the fact that they were free to switch to SWE if they did not want to stay in SSL. Although it was clear from our fieldwork that students sometimes shuttled between the subjects, all of the students in our study chose to stay in SSL throughout their second or third year in upper secondary school.

One essence of policy friction (cf. Jaspers 2015) noted in our data (Hedman and Magnusson 2020b) seems to relate to dominant societal ideologies on "Swedishness", and to what extent students in SSL are part of this social categorization. Wera discussed whether students in SSL were perceived as "real Swedes" and expressed that it was a failure on behalf of the educational system when students born in Sweden studied SSL throughout their schooling (p. 10). Sandra, on the other hand, referred to a specific vulnerability for students in SWE who did not get appropriate support and would benefit from SSL instruction (Hedman and Magnusson 2020b). Another aspect of policy friction concerned the related but not identical issue of who should be considered a first language speaker of Swedish and who a second language speaker, as actualized by the name of the school subject. In Wera's teacher discourse (see excerpt 4), the complexity of the issue appeared; the excerpt begins with a student reading aloud the curricular goal requiring comparisons "between Swedish and your own mother tongue".

\footnotetext{
Excerpt 4. Fieldnotes from Birch (12 May 2016).

Student: [reading the knowledge requirements aloud] "in addition you are able to account for differences between Swedish and your own mother tongue".

That is where your dilemma comes now, which is my mother tongue, which is your

Wera: $\quad$ first language? Now you know Swedish as well as you know your first language-people can learn English, different languages, okay.
}

Wera problematizes the distinction between a mother tongue and Swedish, which, according to her, imposes a "dilemma" for them. As was generally the case, she marks an inclusive stance by including herself among those for whom mother tongue is ambiguous ("which is my mother tongue"). Also, she acknowledges the students' command of Swedish as equal to that of their "first language". By affirming the possibility of learning languages, she seemingly acknowledges a potential of language learning in which the level of command is not necessarily the key issue. Such an attitude is in line with a more dynamic view on multilingual practices and may be seen to challenge the clear-cut division implied by the upper secondary SSL syllabus.

The first/second language division also appeared in the student interviews. For example, one student claimed a self-evident second language status as a motive for her choice of SSL: "But still, well, I am convinced that Swedish is my second language so that [short laughter]" (Hedman and Magnusson 2020a, p. 6). However, among other students who had lived in Sweden since an early age, we found a tendency to dissociate from the category of newly arrived students in the same classroom. One of these students claimed, 
for example, a high command of Swedish and different educational needs than theirs, and maintained that what SSL offered him was support ("language help") in writing and giving speeches, which he distinguished from knowledge of Swedish as such (Hedman and Magnusson 2020a, p. 9). For this student, while recognizing the advantages of SSL instruction, the prospect of being associated with beginner users of Swedish was not a welcome one. The different approaches to students' multilingualism and the multilingual goals of the SSL syllabus, as illustrated in Figure 1, represent an additional kind of policy friction, including different ideologies manifested in teachers' discourses and practices.

In the following, we present our findings from the primary school, Chestnut, where we focus on our observations from the introductory classes and Swedish as a second language.

\section{Sub-Study II: The Primary School}

Sub-study II was located at a primary school (student ages 6-12) in a high-dense migrant area with low socioeconomic status. The school, Chestnut, had a long experience of catering to a large proportion of recently arrived students, and had arranged for introductory classes taught by licensed and experienced SSL teachers, Maria and Kamilla. These transitional classes focused on Swedish language learning (without a formal curriculum), and the students gradually left the introductory classes for subject-learning in their regular class. In Hedman and Magnusson (2021), we analyzed the pedagogic discourses and practices (see Bernstein 1990) in this transitional space, characterized by exceptional conditions (Obondo 2018) with constant influxes and outfluxes of students. An important part of its "inner logic" (Bernstein [1996] 2000) was the collaboratively created space for "emotional understanding" (Hargreaves 2001, in Hedman and Magnusson 2021).

In the regular class, the recently arrived students continued to study SSL as a school subject. Here, we discuss some pedagogical principles also in SSL (see Bernstein 1990), on the basis of observations of a literacy theme taught by Maria. Collected data consist of fieldnotes, photos and teaching materials, and we also conducted audio-recorded interviews with each of the SSL teachers at the school with respect to their teaching. In this paper, we focus on our fieldwork in the introductory classes and the SSL classes over a span of two years. In addition to observations of lessons (involving about 10-20 students), the fieldwork also included breaks and lunches with teachers and students, as well as related events. Noteworthy is that SSL for younger children is even more scantily researched, and various reports indicate major implementation problems with a low proportion of licensed teachers in SSL (Swedish National Agency for Education 2019). This was, however, not the case at Chestnut. As for SSL in the upper secondary schools, the majority of the students at Chestnut studied SSL.

\subsection{Pedagogical Principles in SSL in Primary School}

As evident from interviews and informal talks with Maria and Kamilla, work on literacies (reading comprehension, and writing various text types) and literature was found to be of main importance also in SSL in primary school. When Maria was asked what she had learned from her long-term experience of being an SSL teacher, she pointed out the need to prepare writing tasks in particular, and to work with a "pre-understanding".

Excerpt 5. Interview with teacher Maria at Chestnut.

Researcher: What is it that you, what would, can you formulate what experiences you've

gathered that this other [inexperienced teacher] doesn't have?

Maria: $\quad \mathrm{m}$ I think I have realized that preunderstanding is very very important.

Researcher $\mathrm{m}$.

Maria: $\quad$ That you help them enormously if you build something or how shall I put it ...

Maria: better to say something before you dump it in front of them [giggles] that you really

Researcher: [Orally, a lot, that you prepare things orally?

Maria: $\quad$ YYes much orally I think you can watch pictures and ... 
Maria points out the need to establish an understanding multimodally, which was exemplified during her thematic work (see further below). Maria also points out the need to let things take time as an important principle of pacing (Hedman and Magnusson 2021, p. 97). As we continued to ask about how she found that the SSL subject had developed over time, she concluded that, at Chestnut, SSL had "the same prestige as Swedish", and that at Chestnut "we are fairly enlightened" (excerpt 6). This suggests that the school's long-term experience of catering to migrant students had accumulated knowledge that may have surpassed many other schools, and that this could be one reason why Maria perceived SSL at Chestnut as having the same prestige as SWE.

Excerpt 6. Interview with teacher Maria at Chestnut.

At least here, here I feel think we are rather enlightened, they understand that it is a

Maria: subject in its own right and that it has the same status as Swedish, I think that it ... well, there are no such discussions even. [ ... ]

So I think everyone benefits from SSL, more than if everybody had, or how shall I put it, say that I have one group, like I have, with almost exclusively SSL students and some occasional Swedish speaking, I think they benefit much more from my thinking SSL, all of them, than if would think Swedish, and then perhaps pick out the SSL students or something.

Researcher: Why is that?

Maria: $\quad$ Because I think the pedagogy is much more like, how can I say, student oriented.

In excerpt 7, Maria also states that the pedagogy in SSL is "student-oriented", which resonates with our findings from SSL in upper secondary school. Also, at Chestnut, the local status of the SSL teachers was found to be high, which is in line with the principal's acknowledgement of their expertise as being crucial for recently arrived students and other students at Chestnut (Hedman and Magnusson 2021). The "pedagogy" in SSL, which Maria refers to-evident also in our classroom observations-is in line with how the SSL teachers in upper secondary school viewed their teaching. Guiding pedagogic principles found at Chestnut (as well as at Pine, Rowan and Birch) related to a sociocultural view of language learning, where planned and interactive scaffolding was vital (Hammond and Gibbons 2005), including the planning, sequencing and pacing of the content (Bernstein [1996] 2000); Hammond and Gibbons (2005) and explicit language pedagogy (cf. Christie 1999). Maria found, in addition, that working with writing in different genres on the basis of Gibbons' teaching and learning cycle (e.g., Gibbons 2006) was helpful, and she thought such work would in fact scaffold all students' writing competencies (interview). This type of approach is supported by the Swedish curriculum and the SSL syllabus.

Excerpt 7 builds on a joint excursion, in which Maria brought a group of approximately 20 fifth graders in SSL (ages 10-11 years) to a farm. The thematic work centered on how food was produced on the farm, which was indicative of the aforementioned student-oriented approach in SSL, reflecting situated as well as embodied and multimodal meaning-making. In excerpt 8, the group is back in class in a teacher-fronted whole class discussion, and Maria wants the group to come up with words that they associate with a photo of a horse from the excursion.

The shared experiences make it possible to build a joint pre-understanding in class, and Maria's initial request for "words" actually invites students to both contribute single words and elaborations, including the specialized term forage. This invitation (line 02) is followed up by Maria via affirmations (e.g., line 04), her own elaborations and recasts (e.g., lines $08,10,14)$, and a request for an elaboration (line 06). This micro interaction ends with an elaboration from one student (line 15), leading to an expansion of the meaning of "forage".

Later in this thematic work, Maria also wrote on the smartboard what the students said in class, which resulted in a jointly produced text, where various key words and connectives ("time words", from fieldnotes) were made explicit in the writing process. The students were finally requested to write a text individually (fieldnotes). Through this work, 
Maria managed to engage a relatively large group of learners with different proficiency levels in Swedish.

Excerpt 7. Fieldnotes from Chestnut (9 September 2016).

01 [Maria shows a picture of a horse on the smartboard]

02 Maria: Yes which word can go with the horse picture?

03 Student 1: $\quad$ That we pat horses.

04 Maria: Yes.

05 Student 2: $\quad$ Forage.

06 Maria: Yes how do you think?

07 Student 2: $\quad$ It's f...

08 Maria: Yes exactly, it's food for animals.

09 Student 3: $\quad$ Forage, eat food, what they do, what they eat.

10 Maria: $\quad$ Exactly, forage is their food and what they eat.

11 Student 4: $\quad$ I raised [my hand] a long time ago.

12 Maria: $\quad$ I see.

13 Stundent 4: In a pen.

14 Maria: $\quad$ May be suitable because it was in a pen.

15 Student 4: I can probably bring forage because first when we came, before we went in, we

$\begin{array}{ll}16 \text { Maria: } & \text { listened to a lady who told us what horses eat and we could try ... }\end{array}$

Also, at this primary school level, they engaged with literature in SSL. In the interview, Maria brought up a previous collaborative literary theme in SSL, which she conducted together with the locally employed Mother Tongue (MT) teacher in Arabic, Omid.

\subsection{Considering Multilingual Aspects through Teacher Collaboration}

In regard to the aforementioned literary theme, the class read the well-known and award-winning children's novel in Sweden "Goodbye Mr. Muffin" (Nilsson and Tidholm 2009), which is an illustrated novel about the death of the Guinea pig Mr. Muffin. The novel has been translated into many languages, including Arabic. In this thematic project, the mother tongue classes in Arabic and SSL classes, for some students, were combined in the readings and discussions of this novel in both languages. Maria concluded that she much appreciated this work, although she did not find there to be enough time for this type of collaboration in SSL. Nevertheless, there was an explicit intention among the teachers to build on the multilingual ecology of Chestnut in the SSL practices (cf. Hedman and Magnusson 2021).

As evident from our fieldwork, multilingual aspects came to the fore in more salient ways in the introductory classes (Hedman and Magnusson 2021). There, the students were scaffolded via languages other than Swedish through the use of different digital tools and programs, and through support from multilingual study mentors to learn subject content in Swedish. A resource was also the Mother Tongue teacher Omid, who collaborated with the SSL teachers in the introductory classes (Hedman and Magnusson 2021). Another resource was Kamilla's own multilingual repertoire, and shared experiences of immigration and Swedish language learning, which she could draw on as an asset (Hedman and Magnusson 2021), like Wera in upper secondary school. This is indicative of how teachers in SSL may also engage with the whole multilingual repertoire of the students.

\section{Concluding Discussion}

The analyses and discussions above aim to highlight the complexities involved in the teaching of Swedish in this particular second language-subject design, from the perspectives of teachers and students. This stakeholder perspective, based on classroom ethnography, also allows for an analysis of the high status of SSL locally in the schools under study. In the reported project, an initial criterion was that SSL would not be a rare exception in the schools. Instead, the students in SSL even constituted a majority. We believe this-together with the fact that the teachers' expertise was recognized by colleagues and, in primary 
school, the school management-to have had an impact on the high status of SSL locally. These prerequisites were important, we argue, for the contrastive insights (Hymes 1996) as opposed to previous reported negative conceptions of SSL as low status (Hedman and Magnusson 2020a, 2020b). Moreover, our findings show the importance of highly qualified teachers for second language teaching, which favors students' learning and well-being. This is also one reason why we focused on schools at upper secondary level, where the students can choose between SSL or SWE, and where the teachers were highly qualified and experienced. A methodological point was to study practices where SSL could be realized in accordance with its intentions, and, in upper secondary school, without lock-in effects.

Some discourses on SSL, as reported in Hedman and Magnusson (2018), also resonate with mainstreaming discourses on second language teaching and policies in other countries such as England (Leung 2012, 2016, 2019; see also Conteh 2018). An important point is that mainstreaming proposals are generally not based on language learning motives, which neither was the case in England, where the separation of students was a main concern (Leung 2016; cf. Kulbrandstad and Kulbrandstad 2008, in the Norwegian context). Instead, the mainstreaming process and structural integration of EAL students has led to a "deemphasizing of EAL" (Leung 2019, p. 309). A mainstreaming process in the Swedish context would run the risk of jeopardizing accumulated knowledge and practices related to second language and multilingual development, including the type of scaffolding of advanced language and literature found in our project. Moreover, Creese (2010) has shown how a range of difficulties evolve when the second language teacher's work is reduced to auxiliary functions in other subjects, as compared to teaching a subject with a syllabus. The latter may ensure a certain sustainability of subject knowledge and add to the status of the teacher and subject content. These proposals and empirical data show some of the tensions or policy frictions relating to the complexities of language educational policies aimed at language learning students.

Apart from the reported benefits of pedagogical scaffolding, in all the schools, the multilingual aspects included in the SSL syllabus were also found to be of value to the students. It is noteworthy that knowledge on the role of multilingualism, as well as on second language development and assessment, form part of the SSL teachers' own education and qualifications, as an essential constituent of this type of language provision. Such professional qualifications require a teacher education that is firmly based in research on multilingual and second language teaching and theory, and related aspects. In the shaping of macro policy, these complex aspects, including the notion of equity, need to be considered to reach sustainable and fair educational goals.

Author Contributions: The authors contributed equally regarding all stages in the research process. All authors have read and agreed to the published version of the manuscript.

Funding: The project was funded by the Erik Wellander Foundation.

Institutional Review Board Statement: Ethical review and approval were waived for this study, as it does not treat sensitive personal data (such as religion or political beliefs). The study follows the ethical guidelines of the Swedish Research Council.

Informed Consent Statement: Informed consent was obtained from all participants in the study.

Data Availability Statement: The data presented in this study are available on request from the corresponding authors. The data are not publicly available and available with restrictions due to ethical reasons, to protect the integrity of the participants.

Conflicts of Interest: The authors declare no conflict of interest. 


\section{Appendix A. Original Transcripts in Swedish}

Excerpt 1. Fieldnotes from Pine (15 March 2017).

Här har du blandat ihop lite tror jag. Först ska du ge exempel på när hon upptäckte

Sandra: klass, det var ju när hon började på konstskola. Och då undrar man vad hände där? Vi vill ha exempel. Vad hände där, vad upplevde hon? För nu har vi fått en inledning, vad är det för skillnad? Det är inte bara ekonomi.

Elev: kunskap. Ja och rätt typ av kunskap. Det finns exempel i texten. Men hon berättar också att i ett annat sammanhang när hon var i en butik, då kände hon sig rikare, de andra

Sandra: läste om kärlek, hon läste konsttidningar. Så här vill vi se på exempel, visa skillnaden (SKRIVER). Visa skillnaden på konstskolan och på extrajobbet ... har du upplevt det ... om din familj tycker att du är duktig på fotboll men om du kommer till ett annat sammanhang är kanske inte fotboll viktigt. Har du upplevt det?

Elev: $\quad$ Nej men jag förstår.

Sandra: Du kanske är bra på data.

Elev: $\quad$ Jag är bra på styrketräning.

Sandra: Ja och då om du är på ett ställe där träning är viktigt har du status men här kanske det inte är någon som bryr sig, det är olika status i olika sammanhang.

Elev: $\quad$ Mm / ... /

Sandra: $\quad$ Och så kommer du inte på det där. Och så tänker jag på ordvalet och tempus.

Verbets tidsform. "Han köper inte det nu" hur böjer du det.

Elev: köpte.

Ja ... och fortfarande, här är du influerad av engelskan, "spenderar tid", "spender"

Sandra: $\quad$ är pengar men för tid tycker jag du ska säga "tillbringa" ... "Han känner sig lite kul", vad menar du ... Att han hade roligt? Titta vad som står i texten ... OK.

Excerpt 2. Interview with student Zara at Pine.

Mm på svenska vet inte, asså lärarna förväntade sig att vi skulle kunna det, vi skulle kunna förstå vad som står, och jag hade väldigt svårt med läsförståelse och ändå så hjälpte det inte, vi förväntades kunna allting men, nu sen när jag kom till Wera [sva-läraren] som sa då, då gick hon igenom såhär ännu såhära ännu detaljerad, det

Zara: blev det blev mycket klarare så nu förstår jag saker bättre. Till exempel vi läste Ett öga rött i boken å så vi läste boken, hon hade ju redan tidigare läst den tror jag också. Så när vi inte förstod saker och ting, vi kom och frågade henne så sa hon "ja han säger ju så, vad tror du att det här är", "vad tror du att han säger", "han sa ju så här tidigare, försök å koppla dom å sånt där", hon brukar ge ledtrådsspår, ledtrådar hur vi ska förstå texten.

Forskare Fungerar det bra?

Zara: Ja det fungerade jättebra, jag förstod ... det var första boken jag förstod helt [småskratt].

Excerpt 3. Interview with student Fjodar at Birch.

Forskare Och då undrar vi varför du har valt svenska som andraspråk?

Eh jo svenska som andraspråk och svenska som förstaspråk urskiljer sig ändå en del,

Fjodar: $\quad$ och i svenska som andraspråk en del av kursens mål är att man ska såhär återförenas, känna till sitt modersmål.

Forskare Ja okej.

Fjodar: Kunna knyta till det liksom, för det är ändå ens identitet vem man är som person,

For man kommer ifrån, och det liksom värderar jag så jag vill ha kvar det.

Fjodar: Därför valde jag sva.

Excerpt 4. Fieldnotes from Birch (12 May 2016).

Elev: [läser högt ur kunskapskraven] "dessutom kan du översiktligt redogöra för skillnader mellan svenska och ditt eget modersmål".

Det är där ditt dilemma kommer nu, vilket är mitt modersmål, vilket är ditt första

Wera: språk? Nu kan du svenska lika bra som ditt förstaspråk-man kan lära sig engelska, olika språk, okej. 
Excerpt 5. Interview with teacher Maria at Chestnut.

Forskare: [ . . ] Vad är det du, vad skulle, kan du formulera vad det är du har samlat på dig

för erfarenheter som inte den här andra [oerfarna läraren] har då?

Maria: $\quad m$ jag tror att jag har fattat att förförståelsen är jättejätteviktig.

Forskare: $\mathrm{m}$.

Maria: $\quad$ Att man hjälper dom så enormt mycket om man bygger nånting eller hur ska jag

säga ... bättre å säga nåt innan man slänger fram det [fniss] som man egentligen.

Forskare: [Muntligt mycket att man grundar saker muntligt?

Maria: [Ja mycket muntligt tycker jag att man kan titta på bilder å prata å ...

Excerpt 6. Interview with teacher Maria at Chestnut.

Åtminstone här, här känner tycker jag vi är rätt upplysta, dom förstår att det är ett

Maria: $\quad$ eget ämne och att det är har samma status som svenska tycker jag att det ... ja, det är ingen inga såna diskussioner ens.

[ ... ]Så jag tror att alla tjänar på sva, mer än vad vi skulle tjäna om alla hade, eller ska jag säga om jag säger att jag har en grupp, som jag har nu, med nästan bara sva-elever och nån enstaka svensktalande, jag tror att dom tjänar mycket mer på om jag tänker sva, allihopa, än om jag skulle tänka svenska, och sen kanske plocka ut sva-eleverna eller nånting.

Forskare: Varför då är det så?

Maria: För att jag tycker den pedagogiken är mycket mer så, vad ska man säga, elevtillvänd.

Excerpt 7. Fieldnotes from Chestnut (9 September 2016).

01 [Maria visar en bild på en häst på smartboarden]

02 Maria Ja vilka ord kan passa hästbilden.

03 Elev 1 Att vi klappade hästar.

04 Maria Ja.

05 Elev 2 Foder.

06 Maria Ja hur tänker du?

07 Elev 2 Det är m...

08 Maria Ja precis det är mat till djur.

09 Elev 3 Foder, äter mat, vad dom gör, vad dom äter.

10 Maria Precis, foder är deras mat och vad dom äter.

11 Elev 4 Jag räckte upp [handen] för länge sen.

12 Maria Jag ser.

13 Elev $4 \quad$ En hage.

14 Maria Kan passa för att den stod i en hage.

15 Elev 4 Jag kan nog ta med foder för först när vi, innan vi gick vi in, fick vi höra å en dam som sa vad hästar äter och vi fick pröva ...

16 Maria Ja precis, och hon berättade om en häst som inte kan äta vanligt foder också.

\section{Notes}

1 The paper is partly based on the following articles: Hedman and Magnusson (2018, 2019, 2020a, 2020b, 2021).

2 In this paper, we do not include the additional fieldwork focusing on the work of the Mother Tongue teachers.

3 We use the term "second language student" to refer to students studying SSL, in accordance with the designation of the school subject. The internationally widely used term "additional language" has not been introduced in Swedish education.

4 First teacher or Förstelärare is a category of teacher that secures a higher wage and greater responsibility than other teachers. Promotion to förstelärare may be based on the teacher's education or other criteria, decided by the principal.

\section{References}

Bernstein, Basil. 1990. The structuring of pedagogic discourse. In Volume IV. Class, Codes and Control. London: Routledge.

Bernstein, Basil. 2000. Pedagogy, Symbolic Control and Identity: Theory, Research and Critique. Lanham: Rowman and Littlefield. First published 1996.

Bjuhr, Åsa. 2019. Avslut och fortsättning. En studie om övergången från introduktionsprogrammet språkintroduktion till nationellt program vid gymnasieskolan [Conclusion and continuation]. Ph.D. dissertation, Luleå University of Technology, Luleå, Sweden.

Christie, Frances. 1999. The pedagogic device and the teaching of English. In Pedagogy and the Shaping of Consciousness. Edited by Frances Christie. London: Cassell, pp. 156-84. 
Conteh, Jean. 2018. From the margins to the centre: Multilingual teachers in a monolingual system: Professional identities, skills and knowledge. In The Multilingual Edge of Education. Edited by Piet Van Avermaet, Stef Slembrouck, Koen Van Gorp, Sven Sierens and Katrijn Maryns. London: Palgrave MacMillan, pp. 211-33. [CrossRef]

Copland, Fiona, Sara Shaw, and Julia Snell. 2015. Linguistic Ethnography: Interdisciplinary Explorations. Basingstoke: Palgrave McMillan.

Creese, Angela. 2010. Teaching approaches in two-teacher classrooms. In English as an Additional Language. Approaches to Teaching Linguistic Minority Students. Edited by Constant Leung and Angela Creese. Los Angeles: SAGE, pp. 58-75. [CrossRef]

Emerson, Robert M. 2004. Working with Key Incidents. In Qualitative Research Practice. Edited by Clive Seale, Giampietro Gobo, Jaber F Gubrium and David Silverman. London: SAGE, pp. 427-42.

Fridlund, Lena. 2011. Interkulturell Undervisning-Ett Pedagogiskt Dilemma: Talet om Undervisning i Svenska som Andraspråk och i Förberedelseklasser [Intercultural Education-A Pedagogic Dilema. Talk about Teaching in Swedish as a Second Language and Preparatory Classes]. Ph.D. dissertation, Gothenburg University, Göteborg, Sweden.

Gibbons, Pauline. 2006. Bridging Discourses in the ESL Classroom. London: Continuum. [CrossRef]

Halliday, Michael. 1993. Towards a language-based theory of learning. Linguistics and Education 5: 93-116. [CrossRef]

Hammond, Jennifer, and Pauline Gibbons. 2005. Putting scaffolding to work: The contribution of scaffolding in articulating ESL education. Prospect 20: 6-30.

Hargreaves, Andy. 2001. Emotional geographies of teaching. Teacher College Record 103: 1056-80. [CrossRef]

Hedman, Christina, and Ulrika Magnusson. 2018. Lika eller lika möjligheter? Diskurser om skolämnet svenska som andraspråk inom det akademiska fältet i Sverige [Similar or equal opportunities? Discourses on the school-subject Swedish as a second language within the academic field in Sweden]. Acta Didactica 12: 1-20. [CrossRef]

Hedman, Christina, and Ulrika Magnusson. 2019. Performative functions of multilingual policy in second language education in Sweden. International Journal of Bilingual Education and Bilingualism, 1-15. [CrossRef]

Hedman, Christina, and Ulrika Magnusson. 2020a. Student ambivalence towards second language education in three Swedish upper secondary schools. Linguistics and Education 55: 1-12. [CrossRef]

Hedman, Christina, and Ulrika Magnusson. 2020b. Teachers' acts of legitimation in second language education in Swedish upper secondary schools. Language E Education 34: 535-52.

Hedman, Christina, and Ulrika Magnusson. 2021. Introductory classes for newcomer primary school students in Sweden. Pedagogical principles and emotional understanding. Multicultural Education Review 13: 85-105. [CrossRef]

Hornberger, Nancy. 2005. Opening and filling up implementational and ideological spaces in heritage language education. The Modern Language Journal 89: 605-9. [CrossRef]

Hymes, Dell. 1996. Ethnography Linguistics, Narrative Inequality. London: Taylor \& Francis.

Ivarsson, Marcus. 2013. Selma Lagerlöfs En Herrgårdssägen. [Selma Lagerlöf's A Tale of a Manor]. Stockholm: Kartago.

Jaspers, Jürgen. 2015. Modeling linguistic diversity at school: The excluding impact of inclusive multilingualism. Language Policy 14: 109-29. [CrossRef]

Khemiri, Jonas Hassen. 2003. Ett öga rött. [One Eye Red]. Stockholm: Norstedt.

Kulbrandstad, Lars Anders, and Lise Iversen Kulbrandstad. 2008. Norsk som andrespråk uta rekka gikk-norskopplaering for minoritetsspråklige elever ved et veiskille. In Banebryter og Brogygger i Andrespråksfeltet. En Samling artikler i Anledning Jon Erik Hagens 60-årsdag. Edited by Cecile Hamns Carlsen, Eli Moe, Reidun Andersen and Kari Tenfjord. Bergen: Novus forlag, pp. 39-55.

Lagerlöf, Selma. 1899. En herrgårdssägen. [A Tale of a Manor]. Stockholm: Bonnier.

Leung, Constant. 2012. Second/additional language teacher professionalism—What is it? In Symposium 2012. Edited by Mikael Olofsson. Stockholm: Stockholms universitets förlag, pp. 11-27.

Leung, Constant. 2016. English as an additional language-A genealogy of language-in-education policies and reflections on research trajectories. Language and Education 30: 158-74. [CrossRef]

Leung, Constant. 2019. English as an additional language: Integrating school-aged learners into mainstream curriculum. In Second Handbook of English Language Teaching. Edited by Xuesong Gao. Cham: Springer, pp. 297-315. [CrossRef]

Lindberg, Inger. 2008. Multilingual education: A Swedish perspective. In Education in "Multicultural" Societies. Turkish and Swedish Perspectives. Edited by Marie Carlson, Annika Rabo and Fatma Gök. Swedish Research Institute in Istanbul. Transactions. London: I. B. Tauris \& Co. Ltd., vol. 18, pp. 71-90.

Nilsson, Ulf, and Anna-Clara Tidholm. 2009. Adjö, herr Muffin. [Goodbye, Mr. Muffin]. Stockholm: Bonnier Carlsen.

Obondo, Margaret. 2018. Teachers of newcomer immigrants in provincial schools in Sweden: A quest for culturally responsive teaching in the era of homogenization. Diaspora, Indigenous, and Minority Education 12: 111-23. [CrossRef]

Siekkinen, Frida. 2021. Att vara och inte vara. Elevpositioner(ingar) i Spänningsfältet mellan Svenska och Svenska som Andraspråk. [To be or not to be. Student position(ing)s in the space between Swedish and Swedish as a second language]. Ph.D. dissertation, Gothenburg University, Göteborg, Sweden.

Swedish National Agency for Education. 2013. Curriculum for the Upper Secondary School; Stockholm: Skolverket.

Swedish National Agency for Education. 2017. Kommentarmaterial till Kursplanen i Svenska som Andraspråk. [Comments on the Swedish as a Second Language Syllabus]; Stockholm: Skolverket.

Swedish National Agency for Education. 2019. Elever och Skolenheter i Grundskolan Läsåret 2018/19. [Students and Schools in Compulsory School 2018/2019]; Stockholm: Skolverket. 
Talmy, Steven. 2015. A language socialization perspective on identity work of ESL youth in a superdiverse high school classroom. In The Handbook of Classroom Discourse and Interaction. Edited by Numa Markee. Chichester: Willey Blackwell, pp. 353-68. [CrossRef] Tingbjörn, Gunnar. 2004. Svenska som andraspråk i ett utbildningspolitiskt perspektiv: En tillbakablick [Swedish as a second language from an educational policy perspective: A review]. In Svenska som Andraspråk: I Forskning, Undervisning och Samhälle. [Swedish as a Second Language: In Research, Education and Society]. Edited by Kenneth Hyltenstam and Inger Lindberg. Lund: Studentlitteratur, vol. 1, pp. 743-61.

Torpsten, Ann-Christin. 2008. Erbjudet och Upplevt lärande i mötet med Svenska som Andraspråk och Svensk skola. [Afforded and Experienced Learning in Meeting Swedish as a Second Language and Swedish Schooling]. Ph.D. dissertation, Växjö University, Växjö, Sweden.

Westling Allodi, Mara. 2007. Equal opportunities in educational systems: The case of Sweden. European Journal of Education 42 : $133-46$. [CrossRef] 